Integritas 4.2 (Fall 2014), pp. 23-27.

doi: $10.6017 /$ integritas.v4i2p23

\title{
Response to Katarina Schuth
}

\section{Chester Gillis}

My first reaction to this paper is agreement. On behalf of the entire seminar group, thank you Katarina for such an insightful and timely paper. I have a few comments to make. The first ones are theological and the second ones are educational.

On the theological side, yes, the early church sought to reach out to all communities. Part of the motivation for this was proselytization. As your paper notes, since the Second Vatican Council the Church has had a Pontifical Council for Culture for outreach to all cultures. This Council

assists the Pontiff in the exercise of his supreme pastoral office for the benefit and service of the universal Church and of particular Churches concerning the encounter between the saving message of the Gospel and cultures, in the study of the weighty phenomena of: the rift between the Gospel and cultures; indifference in matters of religion; unbelief. It is also concerned with relationships between the Church and the Holy See and the world of culture; in particular it promotes dialogue with contemporary cultures, so that human civilization may become increasingly open to the Gospel, and so that men and women of science, letters and the arts may know that the Church acknowledges their work as a service to truth, goodness and beauty. ${ }^{\mathrm{I}}$

So the universal Church has not significantly altered its mission since its early years.

1 Description of the Pontifical Council for Culture, at www.vatican.va/roman_curia/pontifical_councils/ cultr/documents/rc_pc_cultr_pro_06061999_en.html.

Chester Gillis is dean of Georgetown College, a professor in the Department of Theology, and the director of the Program on the Church and Interreligious Dialogue in the Berkley Center for Religion, Peace, and World Affairs at Georgetown University. Dr. Gillis is an expert on the U.S. Catholic Church, the history of Catholicism, the papacy, including Pope Benedict XVI, interfaith dialogue, and religious pluralism. He is the author of Roman Catholicism in America; Pluralism: A New Paradigm for Theology; A Question of Final Belief; and Catholic Faith in America; and the editor of The Political Papacy. 
The Vatican II document Nostra Aetate cast the Church into a sustained quest for, and sometimes a conflict about, a soteriology that is both consistent with the teachings of the Church and respectful to other religions. Balancing these important concerns requires careful analysis of, and faithfulness to, the Catholic tradition and a substantive and constructive dialogue with other Christians, other religions, and non-believers. As John Paul II stated in Redemptoris Missio,

The universality of salvation means that it is granted not only to those who explicitly believe in Christ and have entered the church. Since salvation is offered to all, it must be made concretely available to all. ${ }^{2}$

Because the world has shrunk to a global village, the Church, 50 years after the Second Vatican Council, is challenged to construct a new ecclesiology. It must consider not only itself in relation to the modern world, as Vatican II stressed, but also the Church in relationship with the major world religions. This new ecclesiology must not be a mere accounting of differences, or further assessment of what characterizes the Church as unique or superior. Rather, it must be a genuine attempt to understand itself and its role as one among several significant religious traditions. This new vision of ecclesiology must both draw from the rich tradition of Catholic theology and minimally reinterpret, if not refute, much of that tradition.

Christian theologies that continue to interpret the world as strictly Western or strictly Christian are out of touch with the reality of global Christianity and global religion. Any theology that properly understands Christianity to be but one of many religious expressions is faced with the task of reworking Christian theology to reflect that reality. Claims to Christian uniqueness and supremacy must be assessed in the light of similar claims in other religious traditions. To preserve its place in the world of religions Christianity cannot simply repeat its own claims more dogmatically with the expectation that repetition or insistence will coerce conviction. Only a Christianity that sees itself in the context of the world religions makes sense in the twenty-first century. Christian theological provincialism fosters a defensive ghetto mentality that should be left behind.

In the first centuries of the development of Christianity, Christian theology was formulated intentionally to separate itself from other theological and philosophical claims. By distinguishing itself in its theology, Christianity was able to establish itself as an independent and significant force in the religious world. In the present, Christianity must understand itself not in contrast to but in relation to other religious possibilities and traditions.

The theological understanding of mission may be broadened to accommodate this perspective without sacrificing missionary work. This may be accomplished in two ways: I) by approaching missionary work from a perspective of a theology of the reign of God, and 2) by appropriating a proper perspective of the Church as an eschatological entity. First, if one understands mission as contributing to the building of the reign of God, it is possible to understand that reign as encompassing more than Christianity. Thus it

2 Pope John Paul II, Redemptoris Missio 10, online at www.vatican.va. 
is proper to build up the Christian community; but the Christian community does not exhaust the reign of God. Second, the Church itself is incomplete and in process. It is itself an eschatological body moving toward its own fulfillment. It has not yet reached that fulfillment. The Church must be forever open to its future and that future may include relationship to other religious ways of relating to the divine. The Church must be open to new ways of understanding itself and its mission in the world. When understood in terms of salvation, that mission may be shared by others who are also seeking spiritual fulfillment, even if they describe that fulfillment in different terms as a result of diverse cultural and historical circumstances.

One creative suggestion for accomplishing this goal of bringing cultures together is to begin not with the doctrinal differences but with some of the practical concerns. Issues such as the welfare of the environment, the hunger of masses of people, and the poverty of nations are touchstones that each of the great religious traditions might confront within its own context. These are points of common concern. A dialogue among cultures and religions focusing on these issues of human welfare and fostering a common effort to confront the problems of ecology, hunger, and poverty may serve as a point of departure. The common effort to improve human welfare will then serve as a basis for a return to dialogue concerning theological convictions that underlie and legitimate the social efforts of each religion. In Christian terms this might be called a liberation theology of religions.

Katarina has stated: "The more we know of the other...the more likely we are to understand their dreams, their joys and sorrows." On the educational front, all of our colleges and universities are embracing persons from other cultures in a variety of ways. At Georgetown, 57 percent of our students do some form of study aboard, for a year, a semester, or a summer, at 160 programs in 40 countries. We have a Vice President for Global Engagement. We enroll students from i30 countries. All of our College and Foreign Service students are required to master a second language at the advanced level. Georgetown has a distinctive unit within the college called the Faculty of Languages and Linguistics, which teaches Arabic, Catalan, Chinese, French, German, classical and modern Greek, modern Hebrew, Italian, Japanese, Korean, Latin, Persian, Polish, Portuguese, Russian, Spanish, Swahili, Turkish, Ukrainian, and Comparative Literature. The mastery of languages is accompanied by a deeper knowledge of, and appreciation for, culture.

Examples of Georgetown's global curriculum include the Theology department, which provides courses in all of the major world religions. The History department describes its curriculum in the following way: "Our general education courses (in particular the introductory surveys) also offer, to majors and non-majors alike, a model of trans-national, cross-cultural history that raises their awareness of global themes and issues and leads them to examine the interaction of diverse cultures and groups." Georgetown has a School of Foreign Service that requires students to study international relations and has programs in African Studies, Asian Studies, German and European 
Studies, Australian and New Zealand Studies, Russian and East European Studies, Latin American Studies, and Turkish Studies.

Many students come to us with international travel experience, so they have some appreciation of other cultures. Despite this, however, a good number struggle with difference-be it ethnic, religious, racial, sexual, economic, or cultural. They have to learn how to understand the other by getting out of their comfort zone and encountering the other personally in productive conversation and activity. How many of our cafeterias on our campuses self-segregate? To address this issue, Georgetown initiated a program to engage difference in the classroom.

The university website describes it thus:

The Doyle Engaging Difference Program aims to strengthen Georgetown's commitment to engage more deeply with difference and diversity in the global community....[It] include[s] curricular opportunities in the classroom to promote student engagement with themes of difference; broader campus events including an annual student-alumni symposium and a film and culture series, which brings diversity-related films and events to campus; and chances for students studying abroad around the world to reflect on their experiences in cultural settings different from their own. ${ }^{3}$

Faculty volunteer and are trained to be Doyle Faculty Fellows. They receive activity funds for their course, implement a rigorous research paper requirement, and arrange for one or more guest experts to provide feedback on student research. They intentionally integrate discussions about difference into their courses so that students are forced, in an academic setting, to deal with differences. Students may be able to avoid such conversations/encounters in their social life on campus, but they cannot avoid it in class. While studying aboard, students may enroll in a Junior Year Abroad Network which requires them to write a paper about differences in a variety of dimensions of the cultures in which they are a guest, including religion, work, relationships, politics, and social structures.

There is an annual Doyle Student-Alumni Symposium, which brings alumni and the campus community together around issues of engaging difference. Since the program launched in Fall 2009, over I,600 students have taken one of 4I courses taught by Doyle Faculty Fellows from i9 different departments; I68 students have participated in the Junior Year Abroad Network; and 74 Doyle undergraduate fellows have engaged in faculty-supported research projects.

This program ensures that even students who do not study abroad encounter different cultures-geographic and personal-and engage in dialogue that permits those from minority communities (however one defines them) to represent themselves accurately. Ignorance of other cultures and ways of being in the world may contribute to misunderstanding or caricature. Engaging the other in the classroom fosters respect and understanding even if it does not result in agreement. It encourages honest and 
thoughtful disagreement rather than caricature, misunderstanding, and distrust.

All of our students, then, live in, and many will work in, a global context. We should not allow xenophobia to be an option for them. We have a responsibility to introduce them to the world and the world to them. At one time that world was local, then regional, then national. Now, for all of us, it is international and global.

In a recent piece in our student newspaper, The Hoya, a Jesuit professor, Matthew Carnes, S.J., wrote about "bothered excellence":

When Jesuit education works, it bothers. It gets under your skin. It disquiets, and it challenges, even as it goads and encourages and inspires. It is a worldview in which 'mediocrity has no place,' and it resists complacency at all costs. Jesuit education also beckons us into grappling with our world-the real world, as it exists today-and all the ways that it is bothered in its political, economic and social relations. ${ }^{4}$

One of the greatest assets of colleges and universities is the power to convene. At one time we served largely local students. Then many of us became regional. Now most of us are national and all of us serve an international population as well. We have invited the world to our campuses. We are not here to coddle our students, to ensure them jobs, or to assure them that their culture is superior. We are here to educate them, to help them discover and hone their talents, to instill in them a global perspective, and to make them secure in who they are and comfortable with who others are, across the hall and across the globe.

4 Matthew Carnes, S.J., "Bothered Excellence," The Hoya October 31, 2014, at www.thehoya.com/ carnes-the-high-calling-of-bothered-excellence/. 
